\title{
Article \\ Investigation of Attributes Influencing the Attractiveness of Mobile Commerce Advertisements on the Facebook Platform
}

\author{
Donatas Cvirka ${ }^{1}$, Elzè Rudienè ${ }^{1}$ and Mangirdas Morkūnas ${ }^{2, *}$ \\ 1 Business School, Vilnius University, Sauletekio Ave. 22, 10222 Vilnius, Lithuania; \\ ozasrinkodara@newsec.lt (D.C.); elze.rudiene@vm.vu.lt (E.R.) \\ 2 Faculty of Economics and Business Administration, Vilnius University, Sauletekio Ave. 9, \\ 10222 Vilnius, Lithuania \\ * Correspondence: morkunas.mangirdas@evaf.vu.lt
}

check for updates

Citation: Cvirka, Donatas, Elzè

Rudienè, and Mangirdas Morkūnas. 2022. Investigation of Attributes Influencing the Attractiveness of Mobile Commerce Advertisements on the Facebook Platform. Economies 10: 52. https://doi.org/10.3390/ economies10020052

Academic Editor: Aleksander Panasiuk

Received: 26 December 2021

Accepted: 9 February 2022

Published: 19 February 2022

Publisher's Note: MDPI stays neutral with regard to jurisdictional claims in published maps and institutional affiliations.

Copyright: (C) 2022 by the authors. Licensee MDPI, Basel, Switzerland. This article is an open access article distributed under the terms and conditions of the Creative Commons Attribution (CC BY) license (https:/ / creativecommons.org/licenses/by/ $4.0 /)$.

\begin{abstract}
Examining and analyzing the determinants facilitating consumers' intention to buy via mobile commerce platforms have untapped potential when it comes to advertisement potential and perceived advertising value. Therefore, this paper examines various aspects of the advertisements on mobile commerce platforms and analyzes the importance of intention to buy. The goal of the article is to analyze and determine which aspects of the advertisements have an influence on expediting purchase through mobile commerce. The underlying hypothesis for this investigation is the applicability of the perceived advertising value of mobile commerce, positively associated with attitude towards advertising channels. The Facebook social network has been chosen as an advertisement channel as it is the most popular and biggest investment-generated channel. It is also proven that subjective norms are positively associated with the intention to buy via mobile commerce. This, combined with perceived advertising values and attitudes towards Facebook ads on mobile commerce, influenced the intention to buy.
\end{abstract}

Keywords: mobile commerce; Facebook; advertisement; intention to buy

\section{Introduction}

Nowadays, businesses are spending more of their advertising budgets online and placing special attention on social media as it is a new communication space for companies delivering messages to consumers (Tsimonis et al. 2020). Social media marketing and advertising have positive and significant effects on consumers' intention to buy (Maria et al. 2019). According to Koetsier (2019), the Facebook platform is considered a must for any business growth. Therefore, businesses' marketing expenditure on the Facebook platform continued to grow in 2020 from USD 9.9 to 11.6 billion worldwide (Statista 2021). However, to make such investments, successful marketers must understand how to interact with customers on social media to achieve the goals (Lee et al. 2018).

The effects of advertising elements in social media, Facebook included, the intention to buy or click, and any other consumer actions that lead to a sale are a field that is studied well. The impact is found from the different ad elements, such as emotions evoking, especially positivity and humor (Taylor et al. 2011; Wu et al. 2018; Lee et al. 2018), content informativeness level and type (Haj Eid et al. 2020; Lutfie and Marcelino 2020), video ad length (Munsch 2021; Nettelhorst et al. 2020; Raditya et al. 2020), and content design (Al Kurdi and Alshurideh 2021; Xin Teo et al. 2019). The importance in the same matters of information, entertaining content, advertising value, and being credible has also been confirmed by studies (Warsame et al. 2021).

However, Grewal et al. (2016) pointed out the newness of mobile advertising effectiveness exploration. Additionally, it was proven that consumers perceive mobile commerce and e-commerce differently and, therefore, make different related decisions (Maity 2010). The latter study, as well as the findings by Maity and Dass (2014), suggests that marketers 
should differentiate marketing strategy for each platform. Therefore, Dehghani and Tümer (2015) emphasized that there are a lack of studies giving recommendations for mobile advertising specialists on customer behavior, such as motivation, perception, and making decisions, especially by the use of Facebook advertising. This finding is also supported by Shahbaznezhad et al.'s (2021) study, which indicated that content effectiveness on social media in terms of engaging audiences is highly affected by the context and different types of content. Another study by Haj Eid et al. (2020) confirmed that consumers' attitude towards advertisements is influenced by the design of the ad, such as trust, information level, irritation, and interaction, as well as by users' attitudes.

According to Oh et al. (2015), understanding different influence elements of consumers' behavior in social media ads is critical to the further understanding of overall consumer behavior development. Additionally, Deraz (2019) concluded that marketing insights on social networking sites cannot be generalized as a rule for one. Instead, different types of ads for different social platforms should be researched. Therefore, there is a need to explore how to optimize Facebook campaigns by the use of Facebook ad elements in mobile commerce, with the aim of understanding its influence on customer behavior in order to reach business goals.

The paper is structured as follows: the literature review provides a brief scientific overview of the main differences between e-commerce and m-commerce. It also sheds light on the prevailing theoretical streams focused on the determinants of $\mathrm{m}$-commerce and consumers' intentions to buy products through m-commerce platforms. The methodological part introduces hypotheses, research design, and the main reliability indicators. The results section presents the main research findings. The conclusion section generalizes the main insights and provides research limitations and future research directions.

\section{Literature Review}

\subsection{M-Commerce Versus E-Commerce}

Various influential studies have been conducted in order to assess the effectiveness of ecommerce platforms, proposing sophisticated multiple-criteria decision-making techniques for solving this task (Wang et al. 2020,2021). A study by Maity and Dass (2014) concluded that m-commerce should not be perceived in the same way as e-commerce. Additionally, it mentions that marketing strategy managers should consider the information intended to be delivered differently for different commerce types. Therefore, if the budget is low, then communicate the information via m-commerce. However, if the information is more complex and longer, then e-commerce or in-store as a channel should be chosen. Reddy (2014) researched the differences in intention to buy in e-commerce versus m-commerce. It was proven that such consumer behavior is influenced by perceived utility, social influence, and trust. In the study, utility is referred to as "the level of importance that an individual believes a particular technology can have for its use", social influence is the opinions of friends and trusted people, while trust is related to personal confidence. An important aspect to consider is how m-commerce is being adopted. It was found that adoption is affected by social influence, the facilitating conditions, performance, and effort expectancy (Park et al. 2007). Maseeh et al.'s (2020) research found that consumers generally have a positive view of mobile advertising, mainly because it is informative, entertaining, and personalized and helps to make a decision to buy. Others add that not only social influence but also perceived usefulness and perceived ease of use play a vital role in the adoption (Thakur and Srivastava 2013). Similar insights are found by Ghazali et al.'s (2018) study, which states that customers tend to adopt mobile shopping better when it is not difficult to use or navigate the online shop and when it requires low mental effort. Rozina et al. (2021) studied the purchase intent caused by Facebook advertising in mobile commerce, as related to brand equity and image, and confirmed that m-commerce is a different channel for communication. The study of Maity (2010) analyzed consumer decisionmaking in m-commerce; it was found that even though consumers expect $\mathrm{m}$-commerce and e-commerce to be similar, they do perceive them differently. Additionally, the article 
stated that consumers feel more negative (i.e., stressful) about making decisions on mcommerce, and it is different in relation to e-commerce and in-store environments. Lastly, the conclusion and recommendation of the research identified that marketers should give special attention to the advertising information and materials they transmit to consumers via m-commerce channels. The content is also recommended to be simpler when compared with e-commerce advertising.

\subsection{Mobile Commerce Advertising and Intention to Buy}

Tsang et al. (2004) found that users view mobile advertising negatively unless they receive promotions. However, in a more recent study, Maseeh et al. (2020) concluded differently. Their research found that consumers generally have a positive view of mobile advertising, mainly because it is informative, entertaining, and personalized and helps them to make a decision to buy. Additionally, the same study found that purchase intention and mobile ads have significant relationships, while individual consumer perception plays a moderating role only. Cabiles (2019), Hamouda (2018), and Aziza and Dewi (2019) evaluated consumer responses in their research (e.g., click-through rate, purchase intent), as affected by Facebook, Twitter advertising, and other social media marketing platforms. Mishra (2020) analyzed the user response affected by social media advertising in general. In the research of Camoiras-Rodriguez and Varela (2020), the results drove the insights that customers have more positive intention to shop via mobile when the browsing, online shop interface, and information provided are in a friendly and simple manner. The study by Boardman and McCormick (2018) concluded that out of all shopping channels, m-commerce is mostly favored by females in their 20s, and, with age, the likeability of it decreases. Such insights are explained by the reasoning that younger females are looking for ideas, want to experiment with what is new in the market, and value convenience. However, elderly women (in their 60s) preferred physical stores. Over time, consumers who have a favorable attitude towards mobile shopping apps purchase more frequently (McLean et al. 2020). To sum it up, it can be concluded that, nowadays, consumers generally perceive mobile advertising more positively. The most important elements that affect consumer behavior in $\mathrm{m}$-commerce are mobile connection, mobile devices, and social and digital environments (Koukia et al. 2006). Namin et al. (2020) researched and analyzed banner ad messaging effectiveness. The dependent variables were chosen as the number of clicks and the clickthrough rate, whilst independent variables were the design elements of banner ads: static vs. animated, ad size, standard vs. non-standard, which, in turn, affect advertising involvement and effectiveness. It shows the importance of intention to buy for different consumer groups. In addition, Koutsiouris and Vrechopoulos (2009) emphasized the consumer's individual characteristics when using $\mathrm{m}$-commerce services. The latter is supported by Love (2005), who mentioned that we need to investigate individual characteristics towards mobile services, including marketing activities. It is found that extroverts have higher adoption of mobile commerce rates, while neuroticism makes it harder (Zhou and Lu 2011). Consumers' intention to use mobile shopping is highly motivated by the willingness to save and is supported by an openness to change and demotivated by self-efficacy (Gupta and Arora 2017). One of the m-commerce value propositions is personalization. The biggest argument for it is that mobile devices are being used by usually one person only (Clarke 2008), and personalization can easily be achieved with the help of advertising. Mekawiea and Hanyb (2020) and Alalwan (2018) confirmed this in their research-for analyzing purchase intentions in the environments related to m-commerce, psychological factors and social media advertising are very important. Chong (2013) researched in more depth the demographic and motivation aspects in terms of $\mathrm{m}$-commerce usage and personalization. One of the main findings was that consumers tend to use m-commerce services if they find them enjoyable, and this is positively affected by location-based services. The latter includes personalization in terms of advertisements, offers, and discounts, which are important aspects to consider for marketers working with m-commerce. CamoirasRodriguez and Varela's (2020) study suggested that mobile retailers should differentiate 
marketing strategies based on users' personalities. Wu and Hisa's (2008) study analyzed the innovation of e-commerce by distinguishing different recommendations for Internetenabled commerce, mobile commerce, and ubiquitous commerce. Research suggests that businesses working with m-commerce should review and adapt business elements such as reshaping customer value and relationship building in order to match with opportunities and innovate the business. Specifically, the article draws attention to the fact that mcommerce users have the profile of being pressured by time, have work related to mobiles, are young or/and are considered mobile users. Therefore, one of the suggestions is to design marketing strategies for mobile technologies in order to differentiate from the competition and innovate the business organizations, m-commerce included.

\section{Materials and Methods}

\subsection{Hypotheses Building}

\subsubsection{Perceived Informativeness}

Informativeness as an element can be described when the advertisement presents the essential facts and information, preferably in an easy-to-understand manner (Janssens and De Pelsmacker 2005). Such ads are perceived by consumers as useful, enjoyable (Martins et al. 2018), and more reliable (Janssens and De Pelsmacker 2005).

Ducoffe (1996) stated that the perception of an advertisement being useful by providing relevant information leads to the perception of an ad being valuable. Furthermore, Brackett and Carr (2001) also stated the recommendation from their research that the messaging of an ad should be as informative as it can be due to its high influence on perceiving the high value of an ad. The positive effect of an informative ad on perceived advertising value is also concluded from Tsang et al.'s (2004) study. In addition, a direct link between informativeness effects on attitude was found (Brackett and Carr 2001). Therefore, the following hypotheses are formed:

Hypothesis 1 (H1). The perceived informativeness of the mobile ad for $m$-commerce is positively associated with its perceived advertising value on Facebook.

Hypothesis $\mathbf{1}$ (H2). The perceived informativeness of the mobile ad for $m$-commerce is positively associated with the attitude towards Facebook ads.

\subsubsection{Perceived Entertainment}

McQuail (2005) described entertainment as an element that fulfills the need for diversion, enjoyment, or emotional release. The positive link between entertainment and advertisement value is proven by the research of Kim and Han (2014) and Tsang et al. (2004).

In terms of mobile advertising, it was also found that perceived entertainment is one of the most impactful factors for the attitude towards advertising (Yang et al. 2017). The importance of the ad's entertainment to consumers' attitude about advertising was also confirmed by Murillo et al. (2016). Hypotheses H2 and H3 were formed in accordance with the results of previous research.

Hypothesis 3 (H3). The perceived entertainment of the mobile ad for m-commerce is positively associated with its perceived advertising value on Facebook.

Hypothesis 4 (H4). The perceived entertainment of the mobile ad for m-commerce is positively associated with the attitude towards Facebook ads.

\subsubsection{Perceived Irritation}

Irritation is perceived when consumers see the ad as being manipulative, annoying, or offensive (Ducoffe 1996; Lin et al. 2021; Alwreikat and Rjoub 2021). It can also be referred to as a situation when ad messaging irritates and slows down the user (Kim and Han 2014). 
In the mobile context, irritation towards an advertisement can also appear due to the small screen size (Kim and Sundar 2010).

Studies performed by Tsang et al. (2004) and Kim and Han (2014) confirmed that irritation correlates negatively with ad value. Moreover, perceived irritation in the mobile advertising context has also been found to have a negative relationship with advertising value (Koo et al. 2012). Therefore, the further hypothesis is:

Hypothesis 5 (H5). The perceived irritation of the mobile ad for $m$-commerce is negatively associated with its perceived advertising value on Facebook.

\subsubsection{Perceived Credibility}

Advertisement credibility can be described as the perception of the consumer as to truthfulness and believability perceptions (MacKenzie and Lutz 1989; Jaeger and Weber 2020). Credibility was not on the original Ducoffe's advertising value model as an antecedent of advertising value. This element was proposed by Lin and Hung (2009) and Murillo et al. (2016), who found that perceived credibility is significant when it comes to advertising value. Additionally, Haghirian et al.'s (2005) study found that message content credibility positively influences consumer attitudes to mobile ads. Based on the previous research, the hypotheses are stated as:

Hypothesis 6 (H6). The perceived credibility of the mobile ad for m-commerce is positively associated with its perceived advertising value on Facebook.

Hypothesis 7 (H7). The perceived credibility of the mobile ad for m-commerce is positively associated with the attitude towards Facebook ads.

\subsubsection{Perceived Interactivity}

Interactivity can be described as a degree of possibility on which the user can react and act (Florenthal and Shoham 2010). Ching et al.'s (2013) study exploring online advertising effects on attitudes towards products identified that interactivity adds up. Later, it was confirmed that interactivity is a significant factor of influence on the attitude towards online ads (Ariffin et al. 2018). Therefore, the following hypothesis is:

Hypothesis $\mathbf{8}$ (H8). The perceived interactivity of the mobile ad for $m$-commerce is positively associated with the attitude towards Facebook ads.

\subsubsection{Perceived Personalization}

The element of when the advertisement describes and offers a targeted solution to specific users (usually due to acquired information) can be defined as personalization (Shareef et al. 2017). It was found that how consumers perceive ad personalization impacts their attitude, mainly by making users less resistant and lowering skeptical opinions (Baek and Morimoto 2012). Based on the research, the other proposed hypothesis is:

Hypothesis 9 (H9). The perceived personalization of the mobile ad for $m$-commerce is positively associated with the attitude towards Facebook ads.

\subsubsection{Perceived Advertising Value}

According to Tsimonis and Dimitriadis (2019), perceived value has been usually described as the concern between the price paid and the quality received. Based on the original Advertising Value model, Ducoffe (1996) stated that advertising value positively affects consumer attitudes towards ads. Such a relationship has been confirmed by some researchers, who have proved that there is a positive relationship between value and attitude in terms of ads (Murillo et al. 2016). Therefore: 
Hypothesis 10 (H10). The perceived advertising value of the mobile ad for m-commerce is positively associated with the attitude towards Facebook ads.

\subsubsection{Perceived Price}

Nguyen and Gizaw (2014) described "perceived price" as the interpreted individual belief of the product price. Kim et al. (2011) performed a study about internet shopping elements. The research proved that consumers' intention to buy is affected negatively by the product price if it is perceived as high. The following hypothesis has been formed as:

Hypothesis 11 (H11). The perceived price of m-commerce products is negatively associated with the intention to buy.

\subsubsection{Delivery Terms and Conditions}

It is proved that delivery time affects the intention to buy online (Nguyen et al. 2019). However, it is not only related to new customers. It is proven that the client is more likely to come back to purchase again if the seller provides real-time information and accurate expectations about delivery costs and the process (Liu et al. 2019). Based on insights, the following hypothesis states:

Hypothesis 12 (H12). Clear delivery terms and conditions are positively associated with the intention to buy via m-commerce.

\subsubsection{Perceived Risk}

Perceived risk is the uncertainty about the future, usually related to illegal usage of personal and financial information, according to Huang et al. (2014). The study also categorized such risk into categories: economic, performance, psychological, and timerelated. The perceived high risk of a consumer will reduce the purchase intention on e-commerce (Sullivan and Kim 2018). Therefore:

Hypothesis 13 (H13). Perceived risk is negatively associated with the intention to buy via $m$ commerce.

\subsubsection{Attitude towards Ads}

Attitude is "a learned predisposition to consistently behave in a favorable or unfavorable manner with respect to a given object" (Schiffman et al. 2010). The attitude of the consumer is proven to be a reliable prediction of the intention (Gupta and Arora 2017). It has been proven that attitude positively affects the intention to shop online (Jalilvand and Samiei 2012; Raman 2019). Consequently, the hypothesis states:

Hypothesis 14 (H14). Attitude towards Facebook ads is positively associated with the intention to buy via m-commerce.

\subsubsection{Perceived Shopping Platform's Ease of Use}

Ramayah and Ignatius (2010) proved that the description of product selections in terms of ease of use is an unrestricted effort when shopping online. Tsimonis and Dimitriadis (2019) added that ease of use is also related to the website's navigation and downloading

time. Perceived ease of use affects consumers' intention to buy online in a positive way (Akhlaq and Ahmed 2014), mainly because of platform usage convenience as well as an efficient interface (Shankar and Rishi 2020). Sharma and Klein (2020) defined the main elements of an online shopping platform for success, which are: systems, information, design, information, and playfulness. Therefore, the hypothesis is:

Hypothesis 15 (H15). Perceived shopping platform's ease of use is positively associated with the intention to buy via m-commerce. 


\subsubsection{Subjective Norm}

Hasbullah et al. (2016) proved that the subjective norm has a positive correlation with the intention to buy online. Lim et al. (2017), researching social media influencers, also confirmed that the subjective norm is an essential factor for a consumer's intention to purchase. Thus,

Hypothesis 16 (H16). Subjective norm is positively associated with the intention to buy via m-commerce.

The relationships between researched constructs are depicted in a research model below (Figure 1):

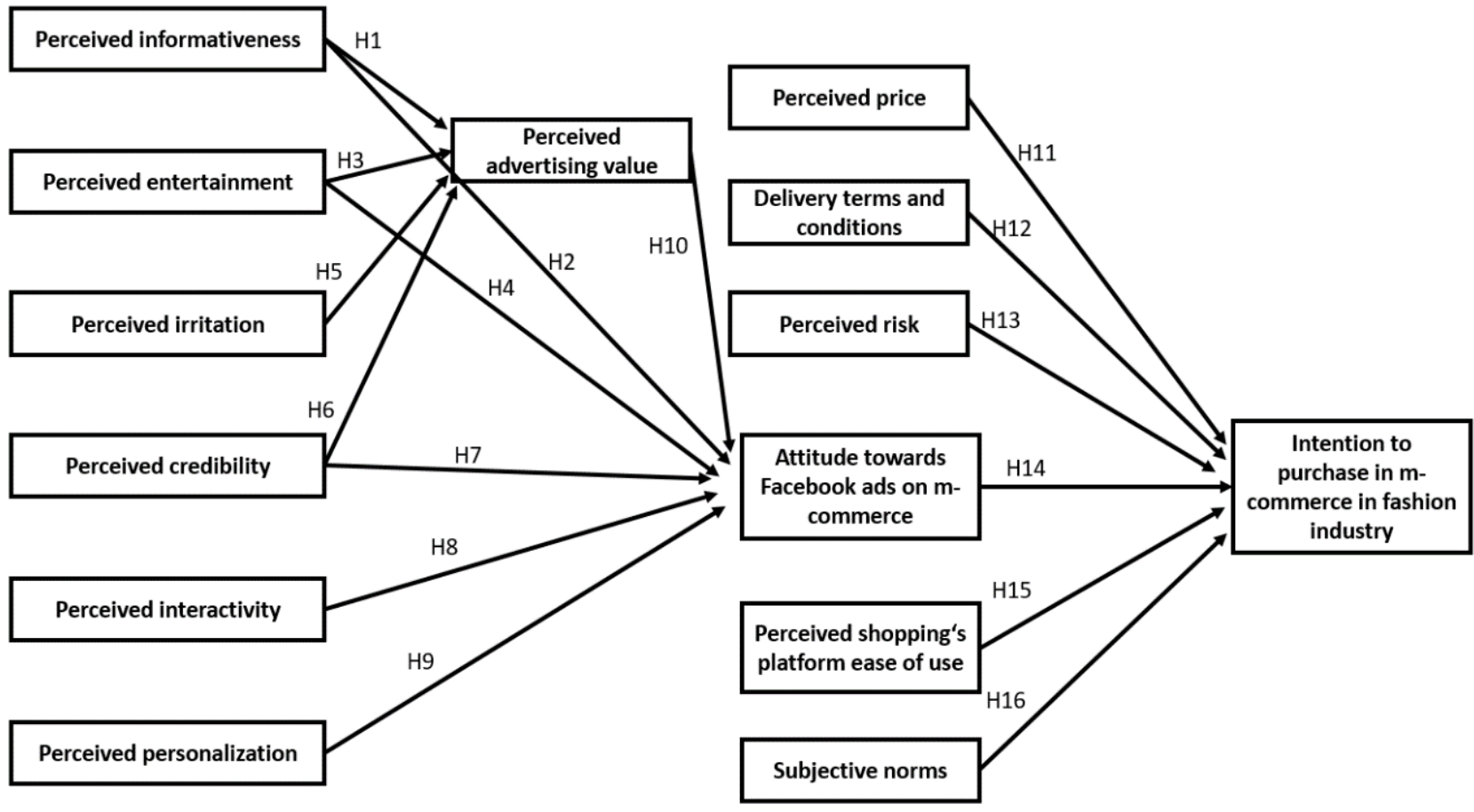

Figure 1. Conceptual research model.

\subsection{Research Design and Reliability Indicators}

We select a research design type-the cross-sectional survey. This type of research is to observe events that are not directly intervened in and that happen naturally, according to Field (2009). Moreover, it helps to see the big picture of a few variables used in a single-time exploration of the natural reactions to the questions reached without third-party interactions. To collect the data for the research, a structured questionnaire is used. It is the most popular instrument for quantitative research as it allows us to receive data from the target population, according to Mathers et al. (1998). The surveys' question responses have the option to be answered from 5 options. These are based on the 5-point Likert scale. The questions of the survey are presented in the Appendix A.

The survey for the research was created using Google Form using the Lithuanian language. It was shared on a Facebook personal wall, stories, and various Facebook groups. In total, 408 individual responses were collected. The data collection took 26 days-from 18 October 2021 to 12 November 2021. All of the respondents were in line with the basic requirements for participating in data analysis: finishing the questionnaire till the end, being Lithuanian, clothes shopping via m-commerce, using Facebook, and being older than 16. Clothing was selected as one of the most popular categories for buying via mobile commerce. IBM SPSS Statistics 28.0 was used for examining data. 
For the evaluation of the reliability and consistency of these scales, the Cronbach's alpha method was applied. Table 1 presents the summary of scale reliability results for variable groups.

Table 1. Scale reliability results.

\begin{tabular}{cccc}
\hline Variable Group & Scale Items & Cronbach's Alpha & Reliability \\
\hline Perceived Informativeness & 5 & 0.896 & Good \\
Perceived Entertainment & 4 & 0.893 & Good \\
Perceived Irritation & 5 & 0.843 & Good \\
Perceived Credibility & 5 & 0.828 & Good \\
Perceived Interactivity & 4 & 0.819 & Good \\
Perceived Personalization & 2 & 0.898 & Poor \\
Perceived Advertising Value & 3 & 0.944 & Good \\
Attitude Towards Facebook Ads & 4 & 0.573 & Poor \\
Perceived Price & 3 & 0.713 & Acceptable \\
Delivery Terms and Conditions & 2 & 0.836 & Good \\
Perceived Risk & 3 & 0.762 & Acceptable \\
Perceived Shopping Platform's Ease of Use & 3 & 0.856 & Good \\
Subjective Norm & 3 & 0.823 & Good \\
\hline
\end{tabular}

Based on Tavakol and Dennick (2011), if Cronbach's alpha is less than 0.5, then the reliability is unacceptable. Poor consistency is when $0.6>\alpha \geq 0.5$; it is questionable if $0.7>$ $\alpha \geq 0.6$, acceptable if $0.8>\alpha \geq 0.7$, good if $0.9>\alpha \geq 0.8$, and excellent if alpha is greater than 0.9. Perceived Personalization and Perceived Price both have Cronbach alphas of just slightly above 0.5 ; therefore, the reliability is considered as poor, and these variables are taken out from further modeling.

In order to check the normality of data distribution, Kolmogorov-Smirnov and Shapiro-Wilk tests were performed. The results are presented in Table 2.

Table 2. Normality of data distribution.

\begin{tabular}{|c|c|c|c|c|c|c|}
\hline \multicolumn{7}{|c|}{ Tests of Normality } \\
\hline & \multicolumn{3}{|c|}{ Kolmogorov-Smirnov } & \multicolumn{3}{|c|}{ Shapiro-Wilk } \\
\hline & Statistic & $\begin{array}{l}\text { Degrees of } \\
\text { Freedom }\end{array}$ & $\begin{array}{c}\text { Significance } \\
\text { Level }\end{array}$ & Statistic & $\begin{array}{l}\text { Degrees of } \\
\text { Freedom }\end{array}$ & $\begin{array}{c}\text { Significance } \\
\text { Level }\end{array}$ \\
\hline Perceived Informativeness & 0.077 & 408 & $<0.001$ & 0.960 & 408 & $<0.001$ \\
\hline Perceived Entertainment & 0.062 & 408 & $<0.001$ & 0.966 & 408 & $<0.001$ \\
\hline Perceived Irritation & 0.105 & 408 & $<0.001$ & 0.977 & 408 & $<0.001$ \\
\hline Perceived Credibility & 0.084 & 408 & $<0.001$ & 0.982 & 408 & $<0.001$ \\
\hline Perceived Interactivity & 0.108 & 408 & $<0.001$ & 0.978 & 408 & $<0.001$ \\
\hline Perceived Advertising Value & 0.087 & 408 & $<0.001$ & 0.965 & 408 & $<0.001$ \\
\hline Attitude Towards Facebook Ads & 0.081 & 408 & $<0.001$ & 0.953 & 408 & $<0.001$ \\
\hline Delivery Terms and Conditions & 0.311 & 408 & $<0.001$ & 0.717 & 408 & $<0.001$ \\
\hline Perceived Risk & 0.119 & 408 & $<0.001$ & 0.919 & 408 & $<0.001$ \\
\hline $\begin{array}{c}\text { Perceived Shopping Platform's } \\
\text { Ease of Use }\end{array}$ & 0.171 & 408 & $<0.001$ & 0.849 & 408 & $<0.001$ \\
\hline Subjective Norm & 0.135 & 408 & $<0.001$ & 0.920 & 408 & $<0.001$ \\
\hline Intention to Purchase & 0.116 & 408 & $<0.001$ & 0.941 & 408 & $<0.001$ \\
\hline
\end{tabular}

\section{Results}

\section{Sample Profile and Demographics}

Out of 408 respondents, the majority were female (88\%), and the rest were male. Such distribution can be explained by each gender's habit of buying clothes. The biggest group of respondents was between 25 to 34 years old (39\%). The second largest group was 35-44year-olds (27\%), then the following: 45 to 54 years old $-15 \%$, up to 24 years old $-12 \%, 55$ to 64 years old $-5 \%$, and 1\% more than 65 years old. In terms of income, the two major groups were earning EUR 500 to 999 per month (33\% of respondents) and EUR 1000 to 1499 
per month $(28 \%)$. The rest of the distribution between the income groups of the participants can be seen in Table 3 .

Table 3. Sample profile.

\begin{tabular}{ccc}
\hline & Gender & \\
\hline Gender & Frequency & Percent \\
Female & 359 & $88 \%$ \\
Male & 49 & $12 \%$ \\
Total & 408 & $100 \%$ \\
\hline & Age & \\
\hline Age & Frequency & Percent \\
25 to 34 & 159 & $39 \%$ \\
35 to 44 & 112 & $27 \%$ \\
45 to 54 & 63 & $15 \%$ \\
Up to 24 & 50 & $12 \%$ \\
55 to 64 & 21 & $5 \%$ \\
More than 65 & 3 & $1 \%$ \\
Total & 408 & $100 \%$ \\
\hline & Income & \\
\hline Monthly income & Frequency & Percent \\
Up to 499 EUR & 43 & $11 \%$ \\
1000-1499 EUR & 133 & $33 \%$ \\
1500-1999 EUR & 115 & $28 \%$ \\
2000-2499 EUR & 56 & $14 \%$ \\
More than 3000 EUR & 34 & $8 \%$ \\
Total & 27 & $100 \%$ \\
\hline
\end{tabular}

As the research is focused on understanding the effect of ads on Facebook, the respondents were asked how often they used Facebook (Table 4). The majority claimed to be using it for $1-2 \mathrm{~h}$ per day (33\%); $25 \%$ were using it for $2-3 \mathrm{~h}$ daily, another $25 \%$ for more than $3 \mathrm{~h}$, and the rest $(18 \%)$ said they were using less than $1 \mathrm{~h}$ per day. Considering the responses, a conclusion can be made that respondents are spending time and, therefore, seeing ads on Facebook.

Table 4. Facebook social media usage.

\begin{tabular}{ccc}
\hline How Often Do You Use Facebook? & Frequency & Percent \\
\hline 1-2 h per day & 133 & $33 \%$ \\
2-3 h per day & 101 & $25 \%$ \\
More than 3 h per day & 100 & $25 \%$ \\
Up to 1 h per day & 74 & $18 \%$ \\
Total & 408 & $100 \%$ \\
\hline
\end{tabular}

Additionally, for the research, it is important to understand the frequency of users purchasing clothes via a mobile habit. Those who do not purchase clothes via mobile at all were asked not to continue filling out the form. The majority of respondents claimed to be buying clothes in such a way once per month to once per half year $(40 \%)$. Two other popular options were "less often than once per year" (20\%) and "from once per week to once per month" (20\%). The full information about the distribution can be seen in Table 5 . 
Table 5. Frequency of buying clothes via mobile.

\begin{tabular}{ccc}
\hline How Often Do You Buy Clothes via Mobile? & Frequency & Percent \\
\hline From once per month to once per half year & 163 & $40 \%$ \\
Less often than once per year & 81 & $20 \%$ \\
From once per week to once per month & 80 & $20 \%$ \\
From once per half year to once a year & 74 & $18 \%$ \\
More than once per week & 10 & $2 \%$ \\
Total & 408 & $100 \%$ \\
\hline
\end{tabular}

The last aspect checked about the respondents were the experience of using smartphones. The vast majority - $63 \%$ of people - claimed to have more than 10 years' experience of using a smartphone. The full distribution is shown in Table 6.

Table 6. Experience using smartphones.

\begin{tabular}{ccc}
\hline Your Experience Using Smartphones & Frequency & Percent \\
\hline More than 10 years & 256 & $63 \%$ \\
7-9 years & 106 & $26 \%$ \\
4-6 years & 34 & $8 \%$ \\
Up to 3 years & 12 & $3 \%$ \\
Total & 408 & $100 \%$ \\
\hline
\end{tabular}

The main descriptive statistics indicators are presented in Table 7. The highest mean of all variables is for Delivery Terms and Conditions, equal to 4.4412, which represents that those respondents agreed that this aspect of buying clothes via m-commerce is important. The lowest mean is for Subjective Norm, equal to 2.3848, which means that this aspect is the least important when buying clothes via m-commerce. The standard deviation is close to 1 , which means that the scales are consistent. However, there are three variables-Perceived Shopping Platform's Ease of Use, Delivery Terms and Conditions, and Perceived Credibility, which present that potential outliers might exist. When looking at the skewness of the variables, it shows different patterns, meaning that not all the results are agreeable.

Table 7. Descriptive statistics.

\begin{tabular}{|c|c|c|c|c|c|c|c|}
\hline \multirow{2}{*}{ Constructs } & \multirow{2}{*}{$\begin{array}{c}\text { Mean } \\
\text { Statistic }\end{array}$} & \multirow{2}{*}{$\begin{array}{c}\begin{array}{c}\text { Std. } \\
\text { Deviation }\end{array} \\
\text { Statistic }\end{array}$} & \multirow{2}{*}{$\begin{array}{l}\text { Variance } \\
\text { Statistic }\end{array}$} & \multicolumn{2}{|c|}{ Skewness } & \multicolumn{2}{|c|}{ Kurtosis } \\
\hline & & & & Statistic & Std. Error & Statistic & Std. Error \\
\hline Perceived Informativeness & 3.4897 & 1.00225 & 1.005 & -0.537 & 0.121 & -0.186 & 0.241 \\
\hline Perceived Entertainment & 2.9369 & 1.11094 & 1.234 & -0.091 & 0.121 & -0.764 & 0.241 \\
\hline Perceived Irritation & 2.8059 & 0.97797 & 0.956 & 0.097 & 0.121 & -0.730 & 0.241 \\
\hline Perceived Credibility & 2.9265 & 0.85997 & 0.740 & -0.223 & 0.121 & -0.242 & 0.241 \\
\hline Perceived Interactivity & 3.1011 & 0.96421 & 0.930 & -0.169 & 0.121 & -0.411 & 0.241 \\
\hline Perceived Advertising Value & 2.7533 & 1.05700 & 1.117 & 0.099 & 0.121 & -0.606 & 0.241 \\
\hline Attitude Towards Facebook Ads & 2.9032 & 1.19548 & 1.429 & -0.027 & 0.121 & -0.933 & 0.241 \\
\hline Delivery Terms and Conditions & 4.4412 & 0.82808 & 0.686 & -1.768 & 0.121 & 3.215 & 0.241 \\
\hline Perceived Risk & 3.7108 & 1.09061 & 1.189 & -0.602 & 0.121 & -0.381 & 0.241 \\
\hline $\begin{array}{l}\text { Perceived Shopping Platform's } \\
\text { Ease of Use }\end{array}$ & 4.2459 & 0.79325 & 0.629 & -1.346 & 0.121 & 2.153 & 0.241 \\
\hline Subjective Norm & 2.3848 & 1.12758 & 1.271 & 0.340 & 0.121 & -0.801 & 0.241 \\
\hline Intention to Purchase & 2.4877 & 1.12056 & 1.256 & 0.442 & 0.121 & -0.724 & 0.241 \\
\hline
\end{tabular}

Taking into account that data sets are non-normally distributed, the Spearman correlation test was performed between all variables. The correlation coefficients of the researched variables are presented in Table 8. 
Table 8. Correlation between variables.

\begin{tabular}{|c|c|c|c|c|c|c|c|c|c|c|c|c|}
\hline Variables & PInf & PEnt & PIrr & PCre & PInt & PAdV & ATFAd & DTCo & PRis & PSPEUs & SNor & IPur \\
\hline PInf & 1 & 0.696 & -0.501 & 0.671 & 0.428 & 0.619 & 0.672 & 0.153 & -0.032 & 0.234 & 0.288 & 0.457 \\
\hline PEnt & 0.696 & 1 & -0.557 & 0.669 & 0.444 & 0.696 & 0.807 & 0.118 & -0.114 & 0.166 & 0.373 & 0.545 \\
\hline PIrr & -0.501 & -0.557 & 1 & -0.48 & -0.243 & -0.488 & -0.594 & -0.072 & 0.306 & -0.177 & -0.117 & -0.298 \\
\hline PCre & 0.671 & 0.669 & -0.48 & 1 & 0.486 & 0.72 & 0.707 & 0.097 & -0.159 & 0.144 & 0.41 & 0.559 \\
\hline PInt & 0.428 & 0.444 & -0.243 & 0.486 & 1 & 0.518 & 0.512 & 0.188 & 0.011 & 0.159 & 0.272 & 0.343 \\
\hline PAdV & 0.619 & 0.696 & -0.488 & 0.72 & 0.518 & 1 & 0.829 & 0.073 & -0.139 & 0.155 & 0.44 & 0.592 \\
\hline ATFAd & 0.672 & 0.807 & -0.594 & 0.707 & 0.512 & 0.829 & 1 & 0.09 & -0.132 & 0.167 & 0.425 & 0.599 \\
\hline DTCo & 0.153 & 0.118 & -0.072 & 0.097 & 0.188 & 0.073 & 0.09 & 1 & 0.165 & 0.42 & 0.073 & 0.073 \\
\hline PRis & -0.032 & -0.114 & 0.306 & -0.159 & 0.011 & -0.139 & -0.132 & 0.165 & 1 & 0.123 & -0.02 & -0.14 \\
\hline PSPEUs & 0.234 & 0.166 & -0.177 & 0.144 & 0.159 & 0.155 & 0.167 & 0.42 & 0.123 & 1 & 0.097 & 0.177 \\
\hline SNor & 0.288 & 0.373 & -0.117 & 0.41 & 0.272 & 0.44 & 0.425 & 0.073 & -0.02 & 0.097 & 1 & 0.622 \\
\hline IPur & 0.457 & 0.545 & -0.298 & 0.559 & 0.343 & 0.592 & 0.599 & 0.073 & -0.14 & 0.177 & 0.622 & 1 \\
\hline
\end{tabular}

Note: Correlation is significant at the 0.01 level (2-tailed).

Before constructing and evaluating the final model based on the results, multicollinearity checks between variables were accomplished. According to Alin (2010), multicollinearity exists between variables if the variance inflation factor (VIF) is more than 3 . No multicollinearity problem was identified.

The hypotheses were tested using regression analysis. After all the statistical checks, the following variables and corresponding hypothesis were excluded from the further research:

- Perceived Personalization (H9) due to poor scale reliability-Cronbach alpha's below 0.5;

- $\quad$ Perceived Price (H11) due to poor scale reliability-Cronbach alpha's below 0.5;

- Perceived Risk (H13) due to weak and negligible correlations with other variables.

Further analysis of hypothesis testing was performed using linear regression. The hypothesis is considered as supported if significance is $p<0.05$.

The first part of the model considers Perceived Advertising Value as a dependent variable. The model equation is: Perceived Advertising Value $=\mathrm{C}+\mathrm{b} 1$ Perceived Informativeness $+b 2$ Perceived Entertainment $+b 3$ Perceived Irritation $+b 4$ Perceived Credibility $+\varepsilon$. The modeling results are presented in Table 9 .

Table 9. Perceived Advertising Value linear regression.

\begin{tabular}{|c|c|c|c|c|c|c|c|}
\hline \multirow{2}{*}{ Construct } & \multicolumn{2}{|c|}{$\begin{array}{l}\text { Unstandardized } \\
\text { Coefficients }\end{array}$} & \multirow{2}{*}{$\begin{array}{c}\begin{array}{c}\text { Standardized } \\
\text { Coefficients }\end{array} \\
\text { Beta } \\
\end{array}$} & \multirow[t]{2}{*}{$t$} & \multirow{2}{*}{ Sig. } & \multicolumn{2}{|c|}{ Collinearity Statistics } \\
\hline & B & Std. Error & & & & Tolerance & VIF \\
\hline (Constant) & 0.258 & 0.236 & & 1.092 & 0.275 & & \\
\hline PInf & 0.128 & 0.051 & 0.121 & 2.497 & 0.013 & 0.411 & 2.436 \\
\hline PEnt & 0.261 & 0.047 & 0.275 & 5.556 & $<0.001$ & 0.397 & 2.52 \\
\hline PIrr & -0.082 & 0.042 & -0.076 & -1.953 & 0.052 & 0.648 & 1.544 \\
\hline PCre & 0.516 & 0.057 & 0.42 & 9.06 & $<0.001$ & 0.452 & 2.215 \\
\hline
\end{tabular}

H1: The perceived informativeness of the mobile ad for m-commerce is positively associated with its perceived advertising value on Facebook.

The hypothesis significance is 0.013 , which is less than 0.05 and is considered statistically significant. Additionally, $\beta=0.121, t=2.497$. To sum up, the $\mathrm{H} 1$ hypothesis is supported.

H3: The perceived entertainment of the mobile ad for m-commerce is positively associated with its perceived advertising value on Facebook.

Hypothesis significance is $<0.001$, which is less than 0.05 and is considered statistically significant. Additionally, $\beta=0.275, t=5.556$. To sum up, the $\mathrm{H} 3$ hypothesis is supported.

H5: The perceived irritation of the mobile ad for $\mathrm{m}$-commerce is negatively associated with its perceived advertising value on Facebook.

Hypothesis significance is 0.052 , which is more than 0.05 and is considered statistically insignificant. Therefore, the $\mathrm{H} 5$ hypothesis is not supported. 
H6: The perceived credibility of the mobile ad for $\mathrm{m}$-commerce is positively associated with its perceived advertising value on Facebook.

The hypothesis significance is $<0.001$, which is less than 0.05 and is considered statistically significant. Additionally, $\beta=0.42, \mathrm{t}=9.06$. To sum $\mathrm{up}$, the H6 hypothesis is supported.

The second part of the model considers Attitude Towards Facebook Ads as a dependent variable. The model equation is: Attitude Towards Facebook Ads $=\mathrm{C}+\mathrm{b} 1$ Perceived Informativeness $+\mathrm{b} 2$ Perceived Entertainment $+\mathrm{b} 3$ Perceived Credibility $+\mathrm{b} 4$ Perceived Interactivity + b5 Perceived Advertising Value $+\varepsilon$. The modeling results are presented in Table 10.

Table 10. Attitude towards Facebook Ads linear regression.

\begin{tabular}{|c|c|c|c|c|c|c|c|}
\hline \multirow{2}{*}{ Construct } & \multicolumn{2}{|c|}{$\begin{array}{l}\text { Unstandardized } \\
\text { Coefficients }\end{array}$} & \multirow{2}{*}{$\begin{array}{c}\begin{array}{c}\text { Standardized } \\
\text { Coefficients }\end{array} \\
\text { Beta } \\
\end{array}$} & \multirow{2}{*}{$t$} & \multirow{2}{*}{ Sig. } & \multicolumn{2}{|c|}{ Collinearity Statistics } \\
\hline & B & Std. Error & & & & Tolerance & VIF \\
\hline (Constant) & -0.402 & 0.113 & & -3.561 & $<0.001$ & & \\
\hline PInf & 0.069 & 0.042 & 0.058 & 1.67 & 0.096 & 0.411 & 2.435 \\
\hline PEnt & 0.417 & 0.038 & 0.388 & 10.876 & $<0.001$ & 0.391 & 2.557 \\
\hline PCre & 0.067 & 0.051 & 0.048 & 1.311 & 0.191 & 0.37 & 2.701 \\
\hline PInt & 0.062 & 0.034 & 0.05 & 1.835 & 0.067 & 0.673 & 1.485 \\
\hline PAdV & 0.527 & 0.041 & 0.466 & 12.718 & $<0.001$ & 0.371 & 2.697 \\
\hline
\end{tabular}

$\mathrm{H} 2$ : The perceived informativeness of the mobile ad for $\mathrm{m}$-commerce is positively associated with the attitude towards Facebook ads.

The hypothesis significance is 0.096 , which is more than 0.05 and is considered statistically not significant. Additionally, $\beta=0.058, \mathrm{t}=1.67$. To sum up, the $\mathrm{H} 2$ hypothesis is not supported.

H4: The perceived entertainment of the mobile ad for $\mathrm{m}$-commerce is positively associated with the attitude towards Facebook ads.

Hypothesis significance is $<0.001$, which is less than 0.05 and is considered statistically significant. Additionally, $\beta=0.388, \mathrm{t}=10.876$. To sum up, the $\mathrm{H} 4$ hypothesis is supported.

H7: The perceived credibility of the mobile ad for $\mathrm{m}$-commerce is positively associated with the attitude towards Facebook ads.

The hypothesis significance is 0.191 , which is more than 0.05 and is considered statistically not significant. Additionally, $\beta=0.048, t=1.311$. To sum $u$, the H7 hypothesis is not supported.

H8: The perceived interactivity of the mobile ad for m-commerce is positively associated with the attitude towards Facebook ads.

The hypothesis significance is 0.067 , which is more than 0.05 and is considered statistically not significant. Additionally, $\beta=0.05, t=1.835$. To sum up, the $\mathrm{H} 8$ hypothesis is not supported.

H10: The perceived advertising value of the mobile ad for $\mathrm{m}$-commerce is positively associated with the attitude towards Facebook ads.

Hypothesis significance is $<0.001$, which is less than 0.05 and is considered statistically significant. Additionally, $\beta=0.466, t=12.718$. To sum up, the $\mathrm{H} 10$ hypothesis is supported.

The third part of the model considers Intention to Purchase on M-Commerce in Fashion Industry as a dependent variable. To make sure the modeling is as accurate as possible, a new variable is introduced-Attitude Towards Facebook Ads Calculated (ATFAdCalc). It is calculated based on the Model-2-supported hypothesis equation: Attitude Towards Facebook Ads Calculated $=-0.137+0.475$ Perceived Entertainment +0.598 Perceived Advertising Value.

The model equation is Intention to Purchase on M-Commerce in Fashion Industry $=\mathrm{C}$ + b1 Attitude Towards Facebook Ads Calculated + b2 Delivery Terms and Conditions + b3 Perceived Shopping Platform's Ease of Use + b4 Subjective Norm $+\varepsilon$. The modeling results are presented in Table 11. 
Table 11. Intention to Purchase linear regression.

\begin{tabular}{|c|c|c|c|c|c|c|c|}
\hline \multirow{2}{*}{ Construct } & \multicolumn{2}{|c|}{$\begin{array}{l}\text { Unstandardized } \\
\text { Coefficients }\end{array}$} & \multirow{2}{*}{$\begin{array}{c}\text { Standardized } \\
\text { Coefficients }\end{array}$} & \multirow{2}{*}{$t$} & \multirow{2}{*}{ Sig. } & \multicolumn{2}{|c|}{ Collinearity Statistics } \\
\hline & B & Std. Error & & & & Tolerance & VIF \\
\hline (Constant) & -0.117 & 0.244 & & -0.481 & 0.631 & & \\
\hline ATFAdCalc & 0.425 & 0.04 & 0.404 & 10.624 & $<0.001$ & 0.771 & 1.296 \\
\hline DTCo & -0.04 & 0.052 & -0.03 & -0.782 & 0.435 & 0.767 & 1.304 \\
\hline PSPEUs & 0.115 & 0.055 & 0.082 & 2.105 & 0.036 & 0.741 & 1.349 \\
\hline SNor & 0.445 & 0.037 & 0.448 & 11.974 & $<0.001$ & 0.798 & 1.252 \\
\hline
\end{tabular}

H12: Clear delivery terms and conditions are positively associated with the intention to buy via m-commerce.

The hypothesis significance is 0.435 , which is more than 0.05 and is considered statistically not significant. Additionally, $\beta=-0.03, \mathrm{t}=-0.782$. To sum up, the H12 hypothesis is not supported.

H14: Attitude towards Facebook Ads is positively associated with the intention to buy via m-commerce.

Hypothesis significance is $<0.001$, which is less than 0.05 and is considered statistically significant. Additionally, $\beta=0.404, \mathrm{t}=10.624$. To sum up, the $\mathrm{H} 14$ hypothesis is supported.

H15: Perceived shopping platform's ease of use is positively associated with the intention to buy via $\mathrm{m}$-commerce.

Hypothesis significance is 0.036 , which is less than 0.05 and is considered statistically significant. Additionally, $\beta=0.082, t=2.105$. To sum up, the $\mathrm{H} 15$ hypothesis is supported.

H16: Subjective norm is positively associated with the intention to buy via m-commerce.

The hypothesis significance is $<0.001$, which is less than 0.05 and is considered statistically significant. Additionally, $\beta=0.448, \mathrm{t}=11.974$. To sum up, the $\mathrm{H} 16$ hypothesis is supported.

To summarize, the hypotheses were tested using empirical research. In total, 3 out of 16 hypotheses could not be tested (H9, H11, H13). The Perceived Personalization and Perceived Price variables were not tested due to poor scale reliability. Perceived Risk was not tested because of weak and negligible correlations with other variables. $\mathrm{H} 2, \mathrm{H} 5, \mathrm{H} 7$, $\mathrm{H} 8$, and $\mathrm{H} 12$ hypotheses were not supported due to insignificance, while $\mathrm{H} 1, \mathrm{H} 3, \mathrm{H} 4, \mathrm{H} 6$, H10, and H14 hypotheses were supported. The summary is provided in Table 12.

Table 12. Hypothesis testing results.

\begin{tabular}{|c|c|c|}
\hline H1 & $\begin{array}{l}\text { The perceived informativeness of the mobile ad for m-commerce is positively } \\
\text { associated with its perceived advertising value on Facebook. }\end{array}$ & Supported \\
\hline $\mathrm{H} 2$ & $\begin{array}{l}\text { The perceived informativeness of the mobile ad for m-commerce is positively } \\
\text { associated with the attitude towards Facebook ads. }\end{array}$ & Not supported \\
\hline H3 & $\begin{array}{l}\text { The perceived entertainment of the mobile ad for } \mathrm{m} \text {-commerce is positively } \\
\text { associated with its perceived advertising value on Facebook. }\end{array}$ & Supported \\
\hline $\mathrm{H} 4$ & $\begin{array}{l}\text { The perceived entertainment of the mobile ad for m-commerce is positively } \\
\text { associated with the attitude towards Facebook ads. }\end{array}$ & Supported \\
\hline H5 & $\begin{array}{l}\text { The perceived irritation of the mobile ad for m-commerce is negatively } \\
\text { associated with its perceived advertising value on Facebook. }\end{array}$ & Not supported \\
\hline H6 & $\begin{array}{l}\text { The perceived credibility of the mobile ad for m-commerce is positively } \\
\text { associated with its perceived advertising value on Facebook. }\end{array}$ & Supported \\
\hline H7 & $\begin{array}{l}\text { The perceived credibility of the mobile ad for m-commerce is positively } \\
\text { associated with the attitude towards Facebook ads. }\end{array}$ & Not supported \\
\hline H8 & $\begin{array}{l}\text { The perceived interactivity of the mobile ad for m-commerce is positively } \\
\text { associated with the attitude towards Facebook ads. }\end{array}$ & Not supported \\
\hline H9 & $\begin{array}{l}\text { The perceived personalization of the mobile ad for m-commerce is positively } \\
\text { associated with the attitude towards Facebook ads. }\end{array}$ & Cannot be tested \\
\hline
\end{tabular}


Table 12. Cont.

\begin{tabular}{|c|c|c|}
\hline H10 & $\begin{array}{l}\text { The perceived advertising value of the mobile ad for m-commerce is positively } \\
\text { associated with the attitude towards Facebook ads. }\end{array}$ & Supported \\
\hline H11 & The perceived price of m-commerce products is negatively associated with the intention to buy. & Cannot be tested \\
\hline H12 & Clear delivery terms and conditions are positively associated with the intention to buy via m-commerce. & Not supported \\
\hline H13 & Perceived risk is negatively associated with the intention to buy via m-commerce. & Cannot be tested \\
\hline H14 & Attitude towards Facebook ads is positively associated with the intention to buy via m-commerce. & Supported \\
\hline H15 & $\begin{array}{l}\text { Perceived shopping platform's ease of use is positively } \\
\text { associated with the intention to buy via m-commerce. }\end{array}$ & Supported \\
\hline H16 & Subjective norm is positively associated with the intention to buy via m-commerce. & Supported \\
\hline
\end{tabular}

The updated conceptual model with the supported hypotheses is presented in Figure 2:

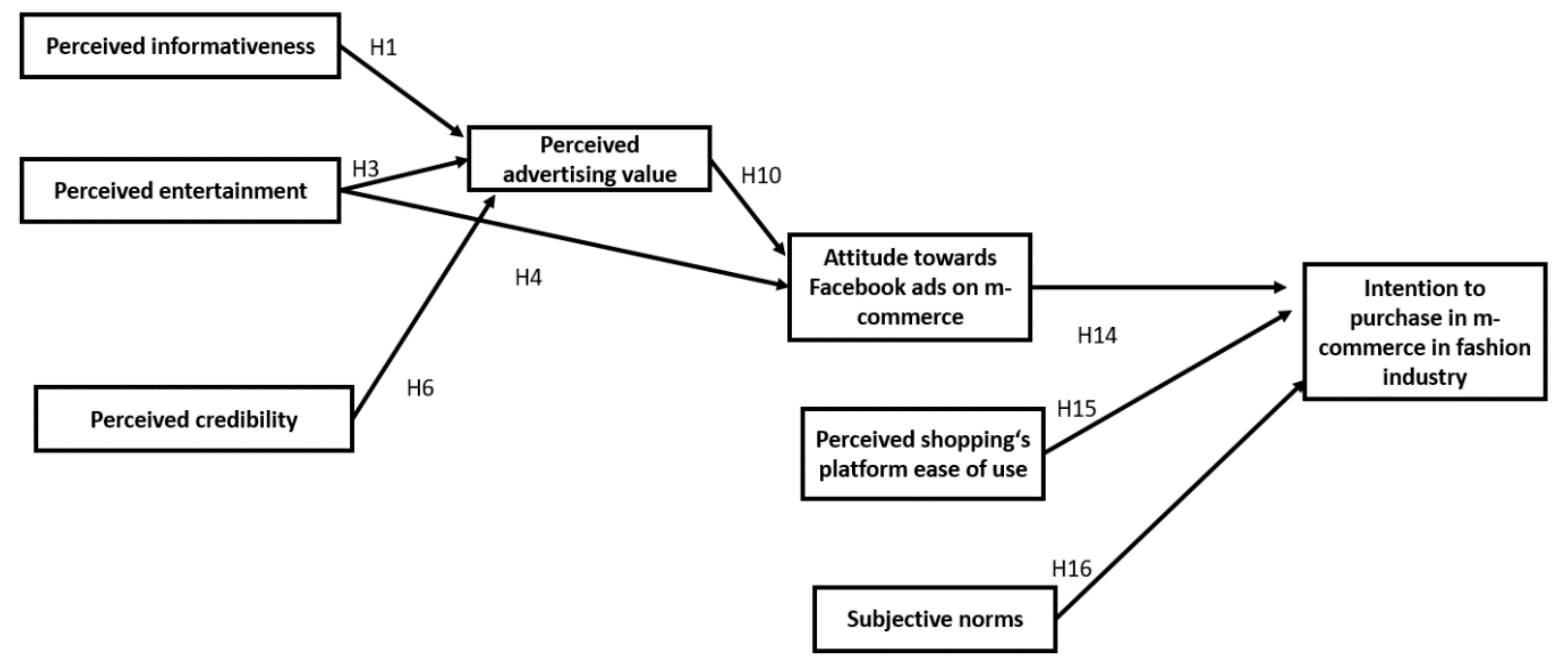

Figure 2. Model with the supported hypotheses.

\section{Conclusions and Discussion}

The theoretical part of our study identified that mobile commerce and e-commerce are found to have differences in consumers' intention to buy. The most important aspects of mobile commerce advertising were found to be users' view, mobile connection, device, digital environments, consumers' individual characteristics, personalization, and innovation.

The survey outcomes confirmed perceived informativeness, perceived entertainment, and perceived credibility as Facebook ads elements that were supported as significant variables of perceived advertising value. Perceived entertainment and perceived advertising value were confirmed as significant variables positively impacting attitudes towards Facebook ads on mobile commerce. The attitude towards Facebook ads on mobile commerce and the perceived shopping platform's ease of use and subjective norm were supported as the main elements influencing consumers' intention to purchase, using mobile commerce, from the fashion industry. The hypotheses were confirmed only partially, which shows the necessity of additional studies in the area of irritation and the interactivity of the mobile ad for mobile commerce with attitudes towards Facebook ads. For further studies, it is recommended to apply for specific brands, perform the study on different industries, and execute globally focused research and/or specify the elements for the respondents. 


\subsection{Managerial Implications}

The direct impact affecting the intention to purchase on $\mathrm{m}$-commerce in the fashion industry in a positive way is affected by three aspects. First is how the platform helps us to perceive the consumers' ease to use when shopping. It is important to make sure that it is easy to choose the product, to operate and understand the platform itself, as well as to take care of the fast downloading and loading time of the platform. Secondly, the subjective norm plays an important role too. Therefore, marketers need to make sure that people important to the consumer, similar to them, as well as those whom they look up to, would encourage them to buy clothes via smartphones. Lastly, the importance lies in the attitude towards Facebook ads, which means that marketers need to make sure that consumers think such ads are a good thing, have a favorable opinion about them, and like them in general.

However, the task to create the desired attitude towards Facebook ads on m-commerce has some aspects that need to be worked on in order to form it in a positive way. The first thing to consider is the perception about Facebook ads being entertaining - it needs to be pleasing and enjoyable. The second thing is the perception of the value that advertisement creates, including usefulness and importance. The research showed that perceived entertainment is an important factor. The other variable to take into account is the credibility the customer perceives. The Facebook ad needs to be convincing, credible, trustworthy, believable, and a useful reference for the purchase. The last contributor is perceived informativeness. It is important to ensure the ads are a good product information source, are relevant, provide timely information, and are up-to-date and convenient.

\subsection{Research Limitations}

The gender distribution is highly unequal as a large majority of the respondents were females. Therefore, a study with equal representation of men and women would be beneficial. Increased sample size may also help to derive additional insights. Furthermore, the respondents were allowed to imagine shopping experiences and ads on Facebook as they wanted to. Such a situation might bring misunderstanding and low consistency between the specific clothing brand cases. To adapt the insights for a specific brand, a more accurate case scenario needs to be given. Additionally, to adapt such research implications for industries other than the clothing industry, another type of literature review is required, and, therefore, the hypotheses and survey questions need to be adapted.

Moreover, to investigate the effect of Facebook ads elements more accurately, exact content examples could be given. This could lead to a more unified understanding of the elements given (i.e., informativeness, entertainment, credibility) as, in this case, it was left to respondents' free interpretation.

Author Contributions: Conceptualization, M.M. methodology, D.C.; validation, D.C and E.R.; formal analysis, E.R.; investigation, D.C.; data curation, D.C.; writing-original draft preparation, E.R.; writing-review and editing, M.M.; project administration, E.R.; funding acquisition, M.M. All authors have read and agreed to the published version of the manuscript.

Funding: This research received no external funding.

Conflicts of Interest: The authors declare no conflict of interest. 


\section{Appendix A}

Table A1. Questionnaire of the Facebook advertising elements.

\begin{tabular}{|c|c|c|}
\hline Variable & Statement & Source \\
\hline \multirow{5}{*}{$\begin{array}{l}\text { Perceived } \\
\text { Informativeness }\end{array}$} & $\begin{array}{l}\text { Clothes ads on Facebook via mobile are good } \\
\text { sources of product information }\end{array}$ & Ducoffe (1996) \\
\hline & $\begin{array}{l}\text { Clothes ads on Facebook via mobile supply } \\
\text { relevant product information }\end{array}$ & Ducoffe (1996) \\
\hline & $\begin{array}{c}\text { Clothes ads on Facebook via mobile provide } \\
\text { timely information }\end{array}$ & Ducoffe (1996) \\
\hline & $\begin{array}{l}\text { Clothes ads on Facebook via mobile are good } \\
\text { sources of up-to-date product information }\end{array}$ & Ducoffe (1996) \\
\hline & $\begin{array}{c}\text { Clothes ads on Facebook via mobile are convenient } \\
\text { sources of product information }\end{array}$ & Ducoffe (1996) \\
\hline \multirow{4}{*}{$\begin{array}{c}\text { Perceived } \\
\text { Entertainment }\end{array}$} & $\begin{array}{l}\text { Clothes ads on Facebook via mobile } \\
\text { are entertaining. }\end{array}$ & Ducoffe (1996) \\
\hline & Clothes ads on Facebook via mobile are pleasing. & Ducoffe (1996) \\
\hline & Clothes ads on Facebook via mobile are enjoyable. & Ducoffe (1996) \\
\hline & Clothes ads on Facebook via mobile are fun. & Ducoffe (1996) \\
\hline \multirow{5}{*}{ Perceived Irritation } & Clothes ads on Facebook via mobile are annoying. & $\begin{array}{c}\text { Ducoffe (1996), } \\
\text { Brackett and Carr (2001) }\end{array}$ \\
\hline & Clothes ads on Facebook via mobile are irritating. & $\begin{array}{c}\text { Ducoffe (1996), } \\
\text { Brackett and Carr (2001) }\end{array}$ \\
\hline & Clothes ads on Facebook via mobile are deceptive. & $\begin{array}{c}\text { Ducoffe (1996), } \\
\text { Brackett and Carr (2001) }\end{array}$ \\
\hline & Clothes ads on Facebook via mobile are confusing. & $\begin{array}{c}\text { Ducoffe (1996), } \\
\text { Brackett and Carr (2001) }\end{array}$ \\
\hline & $\begin{array}{l}\text { Clothes ads on Facebook via mobile insult } \\
\text { people's intelligence. }\end{array}$ & $\begin{array}{c}\text { Ducoffe (1996), } \\
\text { Brackett and Carr (2001) }\end{array}$ \\
\hline \multirow{5}{*}{ Perceived Credibility } & $\begin{array}{l}\text { Clothes ads on Facebook via mobile } \\
\text { are convincing. }\end{array}$ & Brackett and Carr (2001) \\
\hline & Clothes ads on Facebook via mobile are credible. & Brackett and Carr (2001) \\
\hline & $\begin{array}{l}\text { Clothes ads on Facebook via mobile } \\
\text { are trustworthy. }\end{array}$ & Brackett and Carr (2001) \\
\hline & Clothes ads on Facebook via mobile are believable. & Brackett and Carr (2001) \\
\hline & $\begin{array}{l}\text { Clothes ads on Facebook via mobile are useful } \\
\text { references for purchasing products. }\end{array}$ & Brackett and Carr (2001) \\
\hline \multirow{4}{*}{$\begin{array}{c}\text { Perceived } \\
\text { Interactivity }\end{array}$} & $\begin{array}{l}\text { Clothes ads on Facebook via mobile make it easy } \\
\text { to convey my opinion. }\end{array}$ & Kim and Ko (2012) \\
\hline & $\begin{array}{c}\text { Clothes ads on Facebook via mobile allow us to } \\
\text { exchange opinions or conversations with } \\
\text { other users. }\end{array}$ & Kim and Ko (2012) \\
\hline & $\begin{array}{l}\text { Clothes ads on Facebook via mobile allow } \\
\text { two-way interactions with a brand. }\end{array}$ & Kim and Ko (2012) \\
\hline & Clothes ads on Facebook are interactive. & Ching et al. (2013) \\
\hline \multirow{2}{*}{$\begin{array}{c}\text { Perceived } \\
\text { Personalization }\end{array}$} & $\begin{array}{l}\text { Clothes ads on Facebook communicate targeted } \\
\text { solutions and offers to me. }\end{array}$ & Peppers and Rogers (1999) \\
\hline & Clothes ads on Facebook are personalized. & Peppers and Rogers (1999) \\
\hline \multirow{3}{*}{$\begin{array}{c}\text { Perceived } \\
\text { Advertising Value }\end{array}$} & Clothes ads on Facebook via mobile are useful. & $\begin{array}{c}\text { Ducoffe (1996), } \\
\text { Brackett and Carr (2001) }\end{array}$ \\
\hline & Clothes ads on Facebook via mobile are valuable. & $\begin{array}{c}\text { Ducoffe (1996), } \\
\text { Brackett and Carr (2001) }\end{array}$ \\
\hline & Clothes ads on Facebook via mobile are important. & $\begin{array}{c}\text { Ducoffe (1996), } \\
\text { Brackett and Carr (2001) }\end{array}$ \\
\hline
\end{tabular}


Table A2. Questionnaire of elements affecting intention to purchase.

\begin{tabular}{|c|c|c|}
\hline \multirow{4}{*}{$\begin{array}{l}\text { Attitude Towards } \\
\text { Facebook Ads }\end{array}$} & $\begin{array}{c}\text { Clothes ads on Facebook via mobile are a } \\
\text { good thing. }\end{array}$ & Tsang et al. (2004) \\
\hline & I like clothes ads on Facebook via mobile. & Tsang et al. (2004) \\
\hline & $\begin{array}{l}\text { My general opinion about clothes ads on } \\
\text { Facebook via mobile is favorable. }\end{array}$ & Tsang et al. (2004) \\
\hline & $\begin{array}{l}\text { I like to watch clothes ads on Facebook } \\
\text { via mobile. }\end{array}$ & Tsang et al. (2004) \\
\hline \multirow{3}{*}{ Perceived Price } & $\begin{array}{l}\text { When buying clothes via smartphone, price } \\
\text { comparisons between online and offline are } \\
\text { important to me. }\end{array}$ & Wei Yongchang et al. (2018) \\
\hline & $\begin{array}{l}\text { When buying clothes via smartphone, price } \\
\text { promotions are important to me. }\end{array}$ & Wei Yongchang et al. (2018) \\
\hline & $\begin{array}{l}\text { When buying clothes via smartphone, the } \\
\text { price versus performance ratio is important } \\
\text { to me. }\end{array}$ & Wei Yongchang et al. (2018) \\
\hline \multirow{2}{*}{$\begin{array}{l}\text { Delivery Terms and } \\
\text { Conditions }\end{array}$} & $\begin{array}{c}\text { The clarity of delivery terms and conditions } \\
\text { when buying clothes via smartphone is } \\
\text { important to me. }\end{array}$ & Chen et al. (2010) \\
\hline & $\begin{array}{l}\text { The length of delivery time when buying } \\
\text { clothes via smartphone is important to me. }\end{array}$ & Chen et al. (2010) \\
\hline \multirow{3}{*}{ Perceived Risk } & $\begin{array}{l}\text { When buying clothes via smartphone, I } \\
\text { worry about the product quality. }\end{array}$ & Wei Yongchang et al. (2018) \\
\hline & $\begin{array}{l}\text { When buying clothes via smartphone, I } \\
\text { worry about payment privacy. }\end{array}$ & Added by thesis author \\
\hline & $\begin{array}{l}\text { When buying clothes via smartphone, I } \\
\text { worry about the risk of information privacy. }\end{array}$ & Wei Yongchang et al. (2018) \\
\hline \multirow{3}{*}{$\begin{array}{l}\text { Perceived Shopping } \\
\text { Platform's Ease of Use }\end{array}$} & $\begin{array}{l}\text { The ease of choosing the product on a } \\
\text { shopping platform when buying clothes via } \\
\text { smartphone is important to me. }\end{array}$ & Zeithaml et al. (2002) \\
\hline & $\begin{array}{l}\text { The ease of operating and understanding the } \\
\text { shopping platform when buying clothes via } \\
\text { smartphone is important to me. }\end{array}$ & Zeithaml et al. (2002) \\
\hline & $\begin{array}{l}\text { The shopping platform's downloading and } \\
\text { loading time when buying clothes via } \\
\text { smartphone is important to me. }\end{array}$ & Tsimonis and Dimitriadis (2019) \\
\hline \multirow{3}{*}{ Subjective Norm } & $\begin{array}{l}\text { People important to me think I should buy } \\
\text { clothes via smartphone. }\end{array}$ & Mainardes et al. (2020) \\
\hline & $\begin{array}{l}\text { It is expected that people like me should buy } \\
\text { clothes via smartphone. }\end{array}$ & Mainardes et al. (2020) \\
\hline & $\begin{array}{l}\text { People I look up to expect that I should buy } \\
\text { clothes via smartphone. }\end{array}$ & Mainardes et al. (2020) \\
\hline
\end{tabular}

Table A3. Questionnaire on intention to purchase.

\begin{tabular}{ccc}
\hline & $\begin{array}{c}\text { I prefer to buy clothes via mobile } \\
\text { rather than other online or } \\
\text { offline options. }\end{array}$ & Wei Yongchang et al. (2018) \\
\cline { 2 - 3 } Intention to Purchase & $\begin{array}{c}\text { As I see clothes ads on Facebook, I } \\
\text { have the intention to buy clothes } \\
\text { via my smartphone. }\end{array}$ & Taylor and Bearden (2002) \\
\cline { 2 - 3 } & $\begin{array}{c}\text { After seeing clothes ads on } \\
\text { Facebook, I would recommend } \\
\text { them to other people buying } \\
\text { via smartphone. }\end{array}$ & Taylor and Bearden (2002) \\
\hline
\end{tabular}


Table A4. Shortened names of the variables.

\begin{tabular}{cc}
\hline PInf & Perceived Informativeness \\
\hline PEnt & Perceived Entertainment \\
PIrr & Perceived Irritation \\
PCre & Perceived Credibility \\
PInt & Perceived Interactivity \\
PAdV & Perceived Advertising Value \\
ATFAd & Attitude Towards Facebook Ads \\
DTCo & Delivery Terms and Conditions \\
PRis & Perceived Risk \\
PSPEUs & Perceived Shopping Platform's Ease of Use \\
SNor & Subjective Norm \\
IPur & Intention to Purchase \\
\hline
\end{tabular}

\section{References}

Akhlaq, Ather, and Ejaz Ahmed. 2014. Online shopping: A global perspective. Journal of Basic and Applied Scientific Research 4-5: 153-60. Alalwan, Ali Abdallah. 2018. Investigating the impact of social media advertising features on customer purchase intention. International Journal of Information Management 42: 65-77. [CrossRef]

Al Kurdi, Barween, and Muhammad Alshurideh. 2021. Facebook advertising as a marketing tool: Examining the influence on female cosmetic purchasing behaviour. International Journal of Online Marketing (IJOM) 11: 52-74. [CrossRef]

Alin, Aylin. 2010. Multicollinearity. Wiley Interdisciplinary Reviews: Computational Statistics 2: 370-74. [CrossRef]

Alwreikat, Ahmad, and Husam Rjoub. 2021. Impact of Mobile Ad Wearout on Consumer Irritation, Perceived Intrusiveness, Engagement, and Loyalty: A PLS-SEM Analysis. Journal of Organizational and End User Computing (JOEUC) 33: 69-84. [CrossRef]

Ariffin, Shaizatulagma, Aun Kamalul, Lok Tan, and Yashar Salamzadeh. 2018. How personal beliefs influence consumer attitude towards online advertising in malaysia: To trust or not to trust? Global Business and Management Research 10: 30-47.

Aziza, Dhiyaa Nadhifa, and Rifelly Dewi. 2019. Evaluating the effect of Youtube advertising towards young customers' purchase intention. Advances in Economics, Business and Management Research 72: 93-98. [CrossRef]

Baek, Tae Hyun, and Mariko Morimoto. 2012. Stay away from me: Examining the determinants of consumer avoidance of personalized advertising. Journal of Advertising 41: 59-76. [CrossRef]

Boardman, Rosy, and Helen McCormick. 2018. Shopping Channel Preference and Usage Motivations: Exploring Differences Amongst a 50-Year Age Span. Journal of Fashion Marketing and Management: An International Journal 22: 270-84. [CrossRef]

Brackett, Lana, and Benjemin Carr. 2001. Cyberspace advertising vs. other media: Consumer vs. mature student attitudes. Journal of Advertising Research 41: 23-32. [CrossRef]

Cabiles, Victoriano. 2019. 2018 Facebook Advertisement Click-Through Characteristics and User Attitudes. Master's thesis, School of Business London South Bank University, London, UK.

Camoiras-Rodriguez, Zaira, and Conception Varela. 2020. The influence of consumer personality traits on mobile shopping intention. Spanish Journal of Marketing - ESIC 24: 331-53. [CrossRef]

Chen, Ying-Hueih, I-Chieh Hsuand, and Chia-Chen Lin. 2010. Website attributes that increase consumer purchase intention: A conjoint analysis. Journal of Business Research 63: 1007-14. [CrossRef]

Ching, Russell, Pingsheng Tong, and Hung-Yen Chen. 2013. Narrative online advertising: Identification and its effects on attitude toward a product. Internet Research 23: 414-38. [CrossRef]

Chong, Alain Yee-Loong. 2013. Mobile commerce usage activities: The roles of demographic and motivation variables. Technological Forecasting and Social Change 80: 1350-59. [CrossRef]

Clarke, Irvine. 2008. Emerging value propositions for m-commerce. Journal of Business Strategies 25: 41-57. [CrossRef]

Dehghani, Milad, and Mustafa Tümer. 2015. A research on effectiveness of Facebook advertising on enhancing purchase intention of consumers. Computers in Human Behavior 49: 597-600. [CrossRef]

Deraz, Hossam. 2019. Consumers' Responses to Ads on Social Networking Sites: A Systematic Literature Review (SLR). Paper presented at the 17th International Conference on e-Society, Utrecht, The Netherlands, April 11-13.

Ducoffe, Robert. 1996. Advertising value and advertising on the web. Journal of Advertising Research 36: 21-35.

Field, Andy. 2009. Discovering Statistics Using SPSS, 3rd ed. London: SAGE Publications Ltd.

Florenthal, Bela, and Aviv Shoham. 2010. Four-Mode Channel Interactivity Concept and Channel Preferences. Journal of Service Marketing 24: 29-41. [CrossRef]

Ghazali, Ezlika, Dilip Mutum, Jiu Hui Chong, and Bang Nguyen. 2018. Do consumers want mobile commerce? A closer look at $\mathrm{m}$-shopping and technology adoption in Malaysia. Asia Pacific Journal of Marketing and Logistics 30: 1064-86. [CrossRef]

Grewal, Dhruv, Yakov Bart, Martin Spann, and Peter Pal Zubcsek. 2016. Mobile advertising: A framework and research agenda. Journal of Interactive Marketing 34: 3-14. [CrossRef]

Gupta, Anil, and Neelika Arora. 2017. Understanding determinants and barriers of mobile shopping adoption using behavioral reasoning theory. Journal of Retailing and Consumer Services 36: 1-7. [CrossRef] 
Haghirian, Parissa, Maria Madlberger, and Andrea Tanuskova. 2005. Increasing Advertising Value of Mobile Marketing-An Empirical Study of Antecedents. Paper presented at the 38th Hawaii International Conference on System Sciences, Big Island, HI, USA, January 6.

Haj Eid, Mohammed Al, Nawras M. Nusairat, Mahmud Alkailani, and Hamad Al-Ghadeerd. 2020. Internet users' attitudes towards social media advertisements: The role of advertisement design and users' motives. Management Science Letters 10: $2361-70$. [CrossRef]

Hamouda, Manel. 2018. Understanding social media advertising effect on consumers' responses: An empirical investigation of tourism advertising on Facebook. Journal of Enterprise Information Management 31: 426-45. [CrossRef]

Hasbullah, Nurul Aqila, Abdullah Osman, Safizal Abdullah, Shahrul Nizam Salahuddin, Nor Faizzah Ramlee, and Hazalina Mat Soha. 2016. The relationship of attitude, subjective norm and website usability on consumer intention to purchase online: An evidence of Malaysian youth. Procedia Economics and Finance 35: 493-502. [CrossRef]

Huang, Lingling, Juan Feng, and Fengxian Yan. 2014. Study on the perceived risk about the online shopping for fresh agricultural commodities and customer acquisition. Asian Agricultural Research 6: 1-7. [CrossRef]

Jaeger, Anna Katharina, and Anja Weber. 2020. Can you believe it? The effects of benefit type versus construal level on advertisement credibility and purchase intention for organic food. Journal of Cleaner Production 257: 120543. [CrossRef]

Jalilvand, Mohammad Reza, and Neda Samiei. 2012. The impact of electronic word of mouth on a tourism destination choice: Testing the theory of planned behavior (TPB). Internet Research 22: 591-612. [CrossRef]

Janssens, Wim, and Patrick De Pelsmacker. 2005. Emotional or Informative? Creative or Boring? International Journal of Advertising 24: 373-94. [CrossRef]

Kim, Yoo Jung, and Jin Young Han. 2014. Why smartphone advertising attracts customers: A model of web advertising, flow, and personalization. Computer sin Human Behavior 338: 256-69. [CrossRef]

Kim, Nam Young, and Shyam S. Sundar. 2010. Relevance to the Rescue: Can 'Smart Ads' Reduce Negative Response to Online Ad Clutter? Journalism \& Mass Communication Quarterly 87: 346-62. [CrossRef]

Kim, Hee-Wong, Yunjie Xu, and Sumeet Gupta. 2011. Which is more important in internet shopping, perceived price or trust? Electronic Commerce Research and Applications 11: 241-252. [CrossRef]

Kim, Angella. J., and Eunju Ko. 2012. Do social media marketing activities enhance customer equity? An empirical study of luxury fashion brand. Journal of Business Research 65: 1480-86. [CrossRef]

Koetsier, John. 2019. Facebook Getting Too Expensive for Advertisers? Costs Jumped 90\% Year-over-Year. Available online: https:/ / www.forbes.com/sites/johnkoetsier/2019/12/13/facebook-getting-too-expensive-for-advertisers-costs-jumped-90 -year-over-year/?sh=a6149203bca5. (accessed on 15 December 2021).

Koo, Wanmo, Dee K. Knight, Kiseol Yang, and Zheng Xiang. 2012. Generation Y consumers' value perceptions toward apparel mobile advertising: Functions of modality and culture. International Journal of Marketing Studies 4: 56. [CrossRef]

Koukia, Spiridoula, Rigou Maria, and Sirmakessis Spiros. 2006. The role of context in m-commerce and the personalization dimension. Paper presented at the 2006 IEEE/WIC/ACM International Conference on Web Intelligence and Intelligent agent Technology, Hong Kong, China, December 18-22; pp. 267-76.

Koutsiouris, Vasilis, and Adam P. Vrechopoulos. 2009. Developing a user typology in the context of location based mobile services: A multidisciplinary Research Approach. Paper presented at the Mediterranean on Information Systems, Athens University of Economics and Business, AUEB, Athens, Greece, September 25-27.

Lee, Dokyun, Kartik Hosanagar, and Harikesh S. Nair. 2018. Advertising content and consumer engagement on social media: Evidence from Facebook. Management Science 64: 4967-5460. [CrossRef]

Lim, Xin Jean, Jun-Hwa Cheah, and Mun Wai Wong. 2017. The impact of social media influencers on purchase intention and the mediation effect of customer attitude. Asian Journal of Business Research 7: 19. [CrossRef]

Lin, Fen Hui, and Yu Fan Hung. 2009. The value of and attitude toward sponsored links for internet information searchers. Journal of Electronic Commerce Research 10: 235-51.

Lin, Hota Chia-Sheng, Neil Chueh-An Lee, and Yi-Chieh Lu. 2021. The Mitigators of Ad Irritation and Avoidance of YouTube Skippable In-Stream Ads: An Empirical Study in Taiwan. Information 12: 373. [CrossRef]

Liu, Baoshan, Xu Guan, Haijun Wang, and Shihua Ma. 2019. Channel configuration and pay-on-delivery service with the endogenous delivery lead time. Omega 84: 175-88. [CrossRef]

Love, Steve. 2005. Understanding Mobile Human-Computer Interaction, Published by Elsevier Information Systems Series (ISS). Newton: Butterworth Heinemann. [CrossRef]

Lutfie, Harrie, and Dandy Marcelino. 2020. Investigating Facebook advertising feature through performance expectancy on customer purchase intention. Paper presented at the 2020 8th International Conference on Cyber and IT Service Management (CITSM), Pangkal, Indonesia, October 23-24.

MacKenzie, Scott B., and Richard J. Lutz. 1989. An empirical examination of the structural antecedents of attitude toward the ad in an advertising pretesting context. Journal of Marketing 53: 48-65. [CrossRef]

Maity, Moutusy. 2010. Critical factors of consumer decision-making on m-commerce: A qualitative study in the United States. International Journal of Mobile Marketing 5: 87-101.

Mainardes, Emerson Wagner, Irailton Melo de Souza, and Rogério Dias Correia. 2020. Antecedents and consequents of consumers not adopting e-commerce. Journal of Retailing and Consumer Services 55. [CrossRef] 
Maity, Moutusy, and Mayukh Dass. 2014. Consumer decision-making across modern and traditional channels: E-commerce, mcommerce, in-store. Decision Support Systems 61: 34-46. [CrossRef]

Maria, Siti, Tommy Pusriadi, Yundi Permadi Hakim, and Dio Caisar Darma. 2019. The effect of social media marketing, word of mouth, and effectiveness of advertising on brand awareness and intention to buy. Journal Manajemen Indonesia 19: 107-22. [CrossRef]

Martins, José, Catarina Costa, Tiago Oliveira, Ramiro Gonçalves, and Frederico Branco. 2018. How smartphone advertising influences consumers' purchase intention. Journal of Business Research 94. [CrossRef]

Maseeh, Haroon Iqbal, Hafiz Ahmad Ashraf, and Mehak Rehman. 2020. Examining the impact of digital mobile advertising on purchase intention. Review of Integrative Business and Economics Research 9: 84-95.

Mathers, Nigel, Nick Fox, and Amanda Hunn. 1998. Surveys and Questionnaires. Trent: NHS Executive. Available online: https: / / www.rds-yh.nihr.ac.uk/wp-content/uploads/2013/05/12_Surveys_and_Questionnaires_Revision_2009.pdf (accessed on 15 December 2021).

McLean, Graeme, Kofi Osei-Frimpong, Khalid Al-Nabhani, and Hannah Marriott. 2020. Examining consumer attitudes towards retailers' m-commerce mobile applications-An initial adoption vs. continuous use perspective. Journal of Business Research 106: 139-57. [CrossRef]

McQuail, Denis. 2005. Mass Communication Theory, 5th ed. London: Sage Publications Ltd.

Mekawiea, Nermeen, and Aly Hanyb. 2020. Understanding the factors driving consumers' purchase intention of over the counter medications using social media advertising in Egypt: (A Facebook advertising application for cold and flu products). Procedia Computer Science 164: 698-705. [CrossRef]

Mishra, Udgam. 2020. Determination of purchase intention applying technology acceptance model: A case of Facebook influence. Dristikon: A Multidisciplinary Journal 10: 253-264. [CrossRef]

Munsch, Alison. 2021. Millennial and generation z digital marketing communication and advertising effectiveness: A qualitative exploration. Journal of Global Scholars of Marketing Science 31: 10-29. [CrossRef]

Murillo, Enrique, Maria Merino, and Adriana Núñez. 2016. The advertising value of Twitter ads: A study among Mexican millennials. Review of Business Management 18: 436-56. [CrossRef]

Namin, Aidin, Mitchell. L. Hamilton, and Andrew J. Rohm. 2020. Impact of message design on banner advertising involvement and effectiveness: An empirical investigation. Journal of Marketing Communications 26: 115-29. [CrossRef]

Nettelhorst, Stephen, Laura Brannon, Angela Rose, and Whitney Whitaker. 2020. Online viewers' choices over advertisement number and duration. Journal of Research in Interactive Marketing 14: 215-38. [CrossRef]

Nguyen, Dung H., Sander De Leeuw, Wout Dullaert, and Bram P. J. Foubert. 2019. What is the right delivery option for you? Consumer preferences for delivery attributes in online retailing. Journal of Business Logistics 40: 299-321. [CrossRef]

Nguyen, Thu Ha, and Ayda Gizaw. 2014. Factors That Influence Consumer Purchasing Decisions of Private Label Food Products Available online: https://www.diva-portal.org/smash/get/diva2:705384/fulltext01.pdf (accessed on 25 December 2021).

Oh, Jeeyun, Saraswathi Bellur, and Shyam Sundar. 2015. Clicking, assessing immersing, and sharing: An empirical model of user engagement with interactive media. Communication 45: 5. [CrossRef]

Park, Jungkun, Sujin Yang, and Xinran Y. Lehto. 2007. Adoption and usage of mobile technologies for chinese consumers. Journal of Electronic Commerce Research 31: 196-206.

Peppers, Don, and Martha Rogers. 1999. Enterprise One to One. New York: Doubleday.

Raditya, Djoko, Willy Gunadi, Dennis Andariski Setiono, and Jonathan Andreas Rawung. 2020. The effect of ad content and ad length on consumer response towards online video advertisement. Binus Journal Publishing 21: 119-28. [CrossRef]

Raman, Prashant. 2019. Understanding female consumers' intention to shop online: The role of trust, convenience and customer service. Asia Pacific Journal of Marketing and Logistics 31: 1138-60. [CrossRef]

Ramayah, T., and J. Ignatius. 2010. Intention to shop online: The mediating role of perceived ease of use. Middle-East Journal of Scientific Research 5: 152-56.

Reddy, B. V. B. 2014. Phylogenetic analysis of factors that influence customer purchase intention on e-commerce and m-commerce platforms. International Journal of Business, Management and Allied Sciences (IJBMAS) 1: 273-82.

Rozina, Imtiaz, Ahmad Salem Alsoud Malek, Muhammad Sufyan Ramish, Aziz Atif, and Anwar Adnan. 2021. Impact of Facebook on advertising: Analysis of effectiveness of Facebook on enhancing customer purchase intention. Ilkogretim Online - Elementary Education Online 20: 7130-49. [CrossRef]

Schiffman, Leon, Leslie Kanuk, and Joseph Wisenblit. 2010. Consumer Behavior. London: Pearson Prentice Hall.

Shahbaznezhad, Hamidreza, Rebecca Dolan, and Mona Rashidirad. 2021. The role of social media content format and platform in users' engagement behavior. Journal of Interactive Marketing 53: 47-55. [CrossRef]

Shankar, Amit, and Bikramjit Rishi. 2020. Convenience matter in mobile banking adoption intention? Australasian Marketing Journal (AMJ) 28: 273-85. [CrossRef]

Shareef, Mahmud Akhter, Yogesh K. Dwivedi, Vinod Kumar, and Uma Kumar. 2017. Content design of advertisement for consumer exposure: Mobile marketing through short messaging service. International Journal of Information Management 37: $257-68$. [CrossRef]

Sharma, Varinder M., and Andreas Klein. 2020. Consumer perceived value, involvement, trust, susceptibility to interpersonal influence, and intention to participate in online group buying. Journal of Retailing and Consumer Services 52. [CrossRef] 
Statista. 2021. Annual Global Marketing and Sales Costs of Facebook from 2010 to 2020. Available online: https://www.statista.com/ statistics /506867 / facebook-marketing-spending/ (accessed on 15 December 2021).

Sullivan, Yulia W., and Dan J. Kim. 2018. Assessing the effects of consumers' product evaluations and trust on repurchase intention in e-commerce environments. International Journal of Information Management 39: 199-219. [CrossRef]

Tavakol, Mohsen, and Reg Dennick. 2011. Making sense of cronbach's alpha. International journal of medical education 2: 53. [CrossRef]

Taylor, David G., Jeffrey E. Lewin, and David Strutton. 2011. Friends, fans, and followers: Do ads work on social networks? How gender and age shape receptivity. Journal of Advertising Research 51: 258-75. [CrossRef]

Taylor, Valerie, and William Bearden. 2002. The effects of price on brand extension evaluations: The moderating role of extension similarity. Journal of the Academy of Marketing Science 30: 131-140. [CrossRef]

Thakur, Rakhi, and Mala Srivastava. 2013. Customer usage intention of mobile commerce India: An empirical study. Journal of Indian Business Research 5: 52-72. [CrossRef]

Tsang, Melody M., Shu-Chun Ho, and Ting-Peng Liang. 2004. Consumer attitudes toward mobile advertising: An empirical study. International Journal of Electronic Commerce 8: 65-78. [CrossRef]

Tsimonis, Georgios, and Sergios Dimitriadis. 2019. The conceptualization and measurement of perceived value in social media: The case of Facebook brand pages. Paper presented at Academy of Marketing Science Annual Conference, Vancouver, BC, Canada, May 1; pp. 557-67. Available online: https:/ /dora.dmu.ac.uk/bitstream/handle/2086/17589/AMA_2019.pdf?sequence=1\& isAllowed=n (accessed on 15 December 2021).

Tsimonis, Georgios, Sergios Dimitriadis, and Suha Omar. 2020. An integrative typology of relational benefits and costs in social media brand pages. International Journal of Market Research 62: 216-33. [CrossRef]

Wang, Chia-Nan, Thanh-Tuan Dang, and Hsien-Pin Hsu. 2021. Evaluating sustainable last-mile delivery (LMD) in B2C E-commerce using two-stage fuzzy MCDM approach: A case study from Vietnam. IEEE Access 9: 146050-67. [CrossRef]

Wang, Chia-Nan, Thanh-Tuan Dang, Ngoc-Ai-Thy Nguyen, and Thi-Thu-Hong Le. 2020. Supporting better decision-making: A combined grey model and data envelopment analysis for efficiency evaluation in e-commerce marketplaces. Sustainability 12: 10385. [CrossRef]

Warsame, Said Ali, Algeji Abdullah Faeq Mohammed, Mohammed Abdulsalam Elamir, Abdul Aziz, and Nur Azrina Izni Binti. 2021. The Influence of social media advertising values on consumers purchasing intention in Somalia. International Fellowship Journal of Interdisciplinary Research 1: 91-112. [CrossRef]

Wei Yongchang, Can Wang, Song Zhu, Hailong Xue, and Fangyu Chen. 2018. Online purchase intention of fruits: Antecedents in an integrated model based on technology acceptance model and perceived risk theory. Frontiers in Psychology 9: 1521. [CrossRef]

$\mathrm{Wu}$, Chienhsing, Didi Sundiman, Shu-Chen Kao, and Cheng-Hua Chen. 2018. Emotion induction in click intention of picture advertisement: A field examination. Journal of Internet Commerce 17: 356-82. [CrossRef]

$\mathrm{Wu}$, Jen-Her, and Tzyh-Lih Hisa. 2008. Developing e-business dynamic capabilities: An analysis of e-commerce innovation from i-, m-, to u-Commerce. Journal of Organizational Computing and Electronic Commerce 18: 95-111. [CrossRef]

Xin Teo, Li, Ho Keat Leng, and Yi Xian Philip Phua. 2019. Marketing on Instagram: Social influence and image quality on perception of quality and purchase intention. International Journal of Sports Marketing and Sponsorship 20: 321-32. [CrossRef]

Yang, Keng Chieh, Chai Hui Huang, Conna Yang, and Su Yu Yang. 2017. Consumer attitudes toward online video advertisement: YouTube as a platform. Kybernetes 46: 840-853. [CrossRef]

Zeithaml, Valarie A., Parsu A. Parasuraman, and Arvind Malhotra. 2002. Service quality delivery through web sites: A critical review of extant knowledge. Journal of the Academy of Marketing Science 30: 362-75. [CrossRef]

Zhou, Tao, and Yaobin Lu. 2011. The effects of personality traits on user acceptance of mobile commerce. International Journal of Human-Computer Interaction 27: 545-61. [CrossRef] 